DOI: 10.46340/ephd.2020.6.4.8

\author{
Olena Tytar, ScD in Philosophy \\ ORCID ID: https://orcid.org/0000-0002-1951-7830 \\ V.N. Karazin Kharkiv National University, Ukraine \\ Natalia Fradkina, PhD in Philosophy \\ ORCID ID: https://orcid.org/0000-0002-2879-3183 \\ National Technical University "Kharkiv Polytechnic Institute», Ukraine
}

\title{
UKRAINIAN-JEWISH CULTURAL RELATIONS IN SLOBOZHANSHCHYNA: PHILOSOPHICAL AND ANTHROPOLOGICAL ASPECT
}

The article analyzes Ukrainian-Jewish cultural relations during late XIX - early XX centuries. The research hypothesis is based on understanding of great influence of Enlightenment and interculturalism discourses on Ukrainian-Jewish cultural relations of modern times in Slobozhanshchyna. The formation of scientific centers (Medical Society, for example) also happens under the influence of Enlightenment discourse, as well as the formation of public societies aimed at labor and life emancipation of the poor. In addition, these are the societies for dissemination of education among Jews. Such activities became a guarantee of solidarity between the Jewish and Ukrainian communities. On the example of Kharkiv, we clarify the features of the city anthropology in Ukrainian culture of XIX - early XX centuries, and these are the formation of urbanism, tolerance and intercultural relations in the modern cultural environment.

Keywords: Jewish culture, Ukrainian culture, Slobozhanshchyna, philosophy of culture, history of culture, modernism, discourse of enlightenment, urbanism, philosophical anthropology.

Formulation of the problem. Kharkiv is the historical center of Slobozhanshchyna, one of the largest cities in Ukraine in the early twentieth century. It was at the same time the main cultural and educational artery. Enlightenment traditions in this city were founded by Hrygory Skovoroda in XVIII century. The basis for them was Skovoroda's doctrine of Sophia, the Wisdom of God, which «constituting a good variety of life, gives signs of higher value of human individuality, reflected from living experience, especially workers, masters of their craft: a farmer, a soldier or a philosopher, the natural involvement of every human being in the paradigm of a certain cause - the role in the universal «theater» - the philosopher sees true human wisdom, sophistry, existential rootedness in being» ${ }^{1}$.

These enlightenment traditions were then, with the opening of the university in 1805 , inherited and developed by a whole galaxy of prominent scientists and public figures, for whom public education became the meaning of a lifetime.

It is very important to rethink the experience of cooperation and solidarity of Ukrainian and Jewish culture in Ukraine, this factor is intensified in the late nineteenth - early twentieth century and needs a thorough understanding in our times, when there is a need for new intellectuals capable of dialogue and correcting existing mistakes in Soviet totalitarian society.

The role of such competent intellectuals is only growing, such as Leonid Finberg, a well-known researcher and director of the Center for the Study of History and Culture of Eastern European Jewry and editorin-chief of the Spirit and Letter publishing house. In his interview on the occasion of Stanislav Vincenz Prize in the fall of 2020, the scientist noted that «the solidarity of Ukrainian and Jewish intellectuals» ${ }^{2}$ is especially important nowadays. Thus, our time is a time of constructive dialogue between different cultures, so the researcher concludes: «In general, in any relationship, Ukrainian-Jewish, Ukrainian-Polish, Ukrainian-

\footnotetext{
${ }^{1}$ Ушкалов, Л. В. (1999). 3 історії української літератури XVII-XVIII століть. Харків: Акта, 53

2 Коцарев, О. (2020). Леонід Фінберг «Дуже важлива солідарність украйнських і єврейських інтелектуалів» (інтерв'ю в рамках фокус-теми Українського ПЕН 2020/2021 «Культура в режимі очікування») <https://lb.ua/culture/2020/11/03/469689_leonid_finberg_duzhe_vazhliva.html?fbclid=IwAR02wVM56LLyOMJDue FvzKJIvH1vcghdEmYV9G5mO4Khh0Rh9yJUY3y-L2o> (2020, жовтень, 21)
} 
Crimean Tatar and others, there are no contradictions that cannot be understood if there is a good will. It is best when intellectuals and scientists deal with these issues, and it is worse when politicians take on these roles» ${ }^{1}$.

Level of research, analysis of recent publications. The topic of interaction between Ukrainian and Jewish cultures is widely covered by modern scholars, in particular Yu. Melamed ${ }^{2}$, A. Morozova, I. Serheeva, L. Sholokhova. In particular, A. Morozova analyzed Jewish spiritual life and education ${ }^{3}$. Economic factors of the development of the Jewish community in Kharkiv in the modern era are analyzed in the works of A. Skidanova ${ }^{4}$, the contribution of the Jewish community in the formation of Slobozhanshchyna culture is covered in the works of E. Kotlyar ${ }^{5}$. The Society for the Dissemination of Education among Jews is analyzed in the intelligence of V. Dotsenko ${ }^{6}$. The year before last, a thorough study of P.R. Magochy and J. PetrovskyStern «Jews and Ukrainians of the Millennium of Coexistence» ${ }^{7}$ is the first systematized work on the history of Jews in Ukraine.

The purpose of the study: to analyze Ukrainian-Jewish cultural relations, their evolution during the late nineteenth - early twentieth centuries, to identify the impact on these relations discourses of education, cultural diversity and multiculturalism, reveal the features of urban anthropology in the Ukrainian culture as an intercultural center.

\section{Outline of the main issues and research results.}

Referring to the history of the settlement of Jews in Kharkiv, Dmytro Bagaliya notes the following view: «Jews settled in Kharkiv a long time ago, probably at the beginning of the 18th century». In the late nineteenth and early twentieth centuries, various societies, groups and organizations played an important role in educational movement; centers of spiritual life of Ukraine, such cultural regions, are formed. V.S. Horsky first of all distinguishes Slobozhanshchyna as one of the main regions, cultural borders allowed such regions to mutually enrich their culture.

We consider border primarily as a special type of cultural discourse that forms certain personal and cultural characteristics, a special type of perception of the world, borderzone is the place of formation of certain type person of the borderzone society.

Borderzone is a certain spatial localization, a region, where the existence of people is inextricably linked with the existence of border derived from it. For the analysis of borderzone and boundary area, it is essential that the border not only stops communication flows, but also allows «transition» through it, thus structuring complex communication processes, so border always directs communication.

$\mathrm{Yu}$. Lotman said that cultural innovations arise at the crossroads of cultures. Innovations always come from the periphery, from cultural outskirts, where dialogue of different cultural programs becomes possible. We perceive another culture through politics, through falsified cultural memory. Typological feature of «border» emphasizes the «closed-open» opposition. F. Brodel in «Structures of Everyday Life» just points to the confined space as the main feature of the city, a safe place that has its own sign system and certainty, so it forms a special semiosphere: «Dictionary» by Forter (1690) defines the concept of «city»: a place where many people live, usually enclosed by walls». For many cities in the West such a «stone ring», built in XIIIXIV centuries, was an external symbol of the conscious desire for independence and freedom, which marked the growth of medieval cities ${ }^{8}$.

\footnotetext{
${ }^{1}$ Коцарев, О. (2020). Леонід Фінберг «Дуже важлива солідарність украӥнських і єврейських інтелектуалів» (інтерв 'ю в рамках фокус-теми Украӥнського ПЕН 2020/2021 «Культура в режимі очікування») <https://lb.ua/culture/2020/11/03/469689_leonid_finberg_duzhe_vazhliva.html?fbclid=IwAR02wVM56LLyOMJDue FvzKJIvH1vcghdEmYV9G5mO4Khh0Rh9yJUY3y-L2o> (2020, жовтень, 21)

${ }^{2}$ Меламед, Е. (2006). Документы по истории и культуре евреев в архивах Киева. Києв: Дух і Літера, 752.

${ }^{3}$ Морозова, А. (2005). Сврейське населення Лівобережної України (Друга половина ХІХ-початок XX ст.): автореферат дисертації на здобуття наукового ступеню кандидата історичних наук. Харків: Харківський національний університет імені В. Н. Каразіна, 24.

${ }^{4}$ Скіданова А. (2011). Торгівля єврейського населення в Харківські губернії (друга половина ХІХ-початок XX ст.). Свреї в етнічній мозайиі украӥнських земель, 62-67.

${ }^{5}$ Котляр, Е. (2011). Еврейский Харьков: Путеводитель по истории, культуре и местам памяти. Харків: Центр сходознавства ХДАДіМ, 172.

${ }^{6}$ Доценко, В О. (2014). Сврейські культурно-просвітницькі товариства українських губерній Російської імперії (кінець ХІХ-початок ХХ ст.). Зб. наук. праць ХНПУ імені Г.С. Сковороди. Серія Історія і географія, 50, 9-14.

${ }^{7}$ Магочій, П.-Р., Петровський-Штерн, Й. (2018). Свреї та украӥниі: тисячоліття співіснування. Ужгород: В.Падяк, 338.

${ }^{8}$ Бродель, Ф. (1986). Структуры повседневности: возможное и невозможное. Т.1. Материальная циивилизация, экономика и капитализм, XV-XVIII в. Москва: Прогресс, 52.
} 
Hence, a historical event, an event in the art text or in the work of art, is overcoming of this forbidden boundary, meaning the actual transition from one system of symbolic communication to another (or in general unsystematicness), and the main event, semantic, plot episode is «the transition of its topos spatial structure» 1 . In the situation of the frontier-border, such a transition becomes a necessity and constantly accompanies a man of the frontier, Ukrainian-Jewish relations in Slobozhanshchyna demonstrate a formation of urban democratic culture, where Ukrainian and Jewish discourse complemented each other, expanding educational space.

Kharkiv is the capital of Slobozhanshchyna, a multicultural and multinational city. Historically, it is home to people of different nationalities: Germans, Poles, Jews, French, British and many others. Therefore, it can be noted that the educational tradition has developed under the influence of different national cultures. From this point of view, the educational activities of Jewish societies opened in Kharkiv in the early twentieth century are of some interest.

In various historical periods, Jews made up close to $10 \%$ of the population of Slobidska Ukraine. However, the representatives of this ethnic group have made a significant contribution to the development of culture in our region.

The first Jews from abroad (Poland and Turkey) began to come to Kharkiv for the annual Epiphany Fair from the beginning of 18th century, some stayed here, and at the end of 18th century a small Jewish community was formed. After the internal conflict, a group of Jews (foreign nationals) appealed to Russian authorities to extend the laws of Russian justice to them. Despite the fact that the Sloboda-Ukrainian province was the only Ukrainian province that was not included in the settlement border, Jews continued to settle in Kharkiv: in the Sloboda-Ukrainian province under the laws of the Russian Empire from 1791 to 1917, those were officially allowed to live who professed Judaism.

During the nineteenth century, the persecution of Kharkiv Jews was observed, but it was not as severe as that of the entire Russian Empire.

In 1814, the first Jewish students appeared in Kharkiv University. Authorities later tried to establish a branch of the Society of Israeli Christians in Kharkiv to assist baptized Jews, but to no avail. Since 1823, there has been a Jewish street (Civil) in Kharkiv. Mostly Jews were engaged in trade. In 1850s, two Jewish communities were registered in Kharkiv, the merchant and the soldier ones, each with its own synagogue and headers, mikwe and slaughterhouses for ritual birds. In 1859, about a hundred of Jewish soldiers (thirty of them with families), about fifty families of Jewish merchants, and twenty Jewish students lived in Kharkiv. Jews were present primarily in three areas: the army (since 1827, Jews could serve in the army), trade (primarily merchants), students (students of the Kharkiv Imperial University).

In the middle of 19th century, the city Jewish community flourished. This coincided with the completion of the construction of Kursk-Kharkiv-Azov railway by S. Polyakov. In 1863, Kharkiv GovernorGeneral Count A.K. Sievers asked the government to give Jews the right to free residence and access as soon as possible. In 1860, about four thousand Jews were involved in the fairs, and in 1863 about 20 thousand. In 1866, Jews made up $20 \%$ of Kharkiv University students ${ }^{2}$.

In 1866, 775 permanent Jews were registered in Kharkiv, in $1867-906$, in $1873-2397$, in 1879 5194. That is, their number grew rapidly. In the 1840s, 525 Karaites lived in Kharkiv; in 1877 their community had a kenasa and a separate cemetery. The Karaites, who were not subject to any discriminatory restrictions, owned eight tobacco trading companies in the city. From the beginning of 1870 s, activity of the Jewish youth of Kharkiv in the social movement was noted.

At the end of XIX century, the city became a major railway, industrial, commercial and financial center. In 1886, banks of the Rubinstein, Rabinovych, and Rosenzweig families, trading houses of the Soifer and Wolkenstein brothers, which had extensive relations with foreign machine-building and textile firms, operated in Kharkiv. Merchant G.Z. Dunaevsky procured bread for export in the province on behalf of Louis Dreyfus \& Co. trading house ${ }^{3}$.

According to 1897 census, there were 9,848 Jews living in Kharkiv (about $8 \%$ of the population). From those, 876 were tailors, 725 were merchants, 487 were servicemen, more than 200 were rentiers, about 200 were in private service, about 200 were in printing, and 150 were metalworkers. Thus, at the beginning of the twentieth century, the population of Kharkiv was more than 200,000, of whom more than 10,000 were Jews,

\footnotetext{
1 Лотман, Ю.М. (1970). Структура художественного текста. Москва: Искусство, 288.

${ }^{2}$ Котляр, Е. (2011). Еврейский Харьков: Путеводитель по истории, культуре и местам памяти. Харків: Центр сходознавства ХДАДіМ, 172

${ }^{3}$ Скіданова А. (2011). Торгівля єврейського населення в Харківські губернії (друга половина XIX - початок XX ст.). Євреї в етнічній мозайиі українських земель, 62-67.
} 
which puts Kharkiv on the second position in the Russian Empire among the cities in terms of Jewish community (the first position was occupied by St. Petersburg). Numerous Jewish communities also existed in other cities of Slobozhanshchina (Lyubotyn, Chuguiv, Lozova, Kupyansk, Izyum) ${ }^{1}$.

In 1900-1917, Jews were holding key positions in financial sphere, they owned whole or partly the Merchant Bank, a branch of St. Petersburg International Bank and the Bank of Azov-Don, and Jewish Loan Society. By 1913, Jews made up 25\% of the merchants of the second guild (54 out of 210) and 90\% of the merchants of the first guild (135 out of 148).

Engineer A. Buras in 1903 created an original system of sewage treatment, which won the Grand Prix the following year at St. Petersburg exhibition. Jewish doctors played an important role in city medical care. All-Russian fame was gained by one of the founders of plastic surgery, dentist M. Fabrikant, ophthalmologist L. Hirshman, university professor psychiatrist I.S. Orshansky and others.

Jews made up the majority of members of Kharkiv Medical Society. Musicians, singers and actors of Jewish origin formed a significant part of the symphony orchestra in Kharkiv Commercial Club, in the troupes of Drama Theater and Russian Opera. In 1901-1902 season, more than 130 Jews performed on Kharkiv stage. Jews were publishers of the local newspapers «Pivdenny Krai», «Meshkanets Pivdnya», «Ranok Pivdnya», and others, and owned most of the city printing houses ${ }^{2}$.

Since the beginning of the twentieth century, there has been a rapid development of Jewish public life. In January 1905, a cheap canteen was open for the Jewish poor, and in April of that year, a group of wealthy Jews led by philanthropist P. Buras (1835-1914) founded the Society for Aid to Poor Jews, which later united all city Jewish charities.

Jewish political organizations of socialist direction took part in the revolutionary events of 1905-1907. From the beginning of the twentieth century, Kharkiv was one of the centers for spreading Zionist literature. In the early 1910s, new synagogues were built in Kharkiv, the largest of which, the Choral Synagogue, was completed in 1913, and its design won an all-Russian competition.

At the beginning of the First World War there was a general gathering of the community, spreading of charitable activities, including the collection of donations for the families of soldiers and the wounded. In August 1914, the Society for Aid to Poor Jews opened an infirmary for the wounded. Soon, Jewish refugees began arriving in Kharkiv, and then the expelled from the war zone. A Jewish craft school from Riga and a number of others from Lithuania and Poland were set up here, and the Committee for Aid to War Victims and Jewish Refugee Labor Office were active. In 1916, Jewish Consumer Society Amateur was opened, and in 1917 Jewish Cooperative Society Unity was opened, too.

At the beginning of the twentieth century a network of educational societies was established, in particular in 1913 there were more than thirty branches of Society for the Dissemination of Education among Jews in Russian Empire, the largest in Odessa (1867), Kyiv (1903), and Kharkiv (1904) ${ }^{3}$.

The society was governed in a very democratical way, with general meeting and steering committee elected by them. All issues at the meeting were solved by majority vote. In addition to educational issues, financial, organizational, founding, auditing, socio-cultural and socio-domestic issues were addressed.

The activities of the company were organized according to the approved plan, the most important were general meeting, during which the chairman was elected, there was reporting for the year, approval of action plan and budget for the next year, and staffing issues. The board of the company included an elected chairman, deputy chairman, treasurer and secretary. In addition to Russian, the native language was used in the meetings, reports were published in the local press or printed in separate brochures. With provision of significant financial assistance, at least one hundred rubles, Society patron could become an honorary member of the society. Patronage was also carried out in order to honor certain family or activity of a prominent person, in order to perpetuate his memory. Admission and annual fees were fixed for full members, presence of all full members was mandatory when resolving important issues, and in case of conflict they were solved by arbitration court of the company. In addition to contributions, the society was financed by income from the working capital, charity evenings and through so-called «box» collection, from boxes located in

\footnotetext{
${ }^{1}$ Морозова, А. (2005). Сврейське населення Лівобережної України (Друга половина ХІХ-початок XX ст.): автореферат дисертації на здобуття наукового ступеню кандидата історичних наук. Харків: Харківський національний університет імені В. Н. Каразіна, 24.

${ }^{2}$ Котляр, Е. (2011). Еврейский Харьков: Путеводитель по истории, культуре и местам памяти. Харків: Центр сходознавства ХДАДіМ, 172.

3 Доценко, В. О. (2014). Сврейські культурно-просвітницькі товариства українських губерній Російської імперії (кінець ХІХ-початок ХХ ст.). 3б. наук. пращь ХНПУ імені Г.С. Сковороди. Серія Історія і географія, 50, 9-14.
} 
synagogues. For example, Kharkiv Society for Aid to Poor Jews in 1911 received a profit of six thousand six hundred and seventy rubles.

\section{Conclusions.}

1. On the basis of public organizations and educational societies of late XIX-early XX centuries Ukrainian-Jewish cultural relations were studied, in their evolution general imperial guidelines for the development of common culture played an important role, as well as national Ukrainian guidelines for democracy, freedom of speech and actions, self-sufficiency of public activity, joint planning of public actions and responsibilities, respect for outstanding people and their activity.

2. Regarding the discourse of the Enlightenment and the Neo-Enlightenment areas, we observe primarily formation of educational centers, general popularization and specific scientific direction (Medical Society, for example), as well as the society to help the poor, their labor and life emancipation, in addition, these are societies for dissemination of education among Jews, societies for promotion of cultural and journalistic activities, in particular theoretical and organizational support of a number of publications. All these guidelines of the Enlightenment coincide with the spirit of interculturality and multiculturalism of Slobozhanshchyna, so they received such support and development here. It was creation of a true cultural elite, a guarantee of solidarity between the Jewish and Ukrainian communities.

3. Thus, based on our study, we can talk about Kharkiv as a city that supported cultural diversity during the nineteenth - early twentieth century, contributed to the development of Ukrainian-Jewish relations, promoted tolerant attitude to Jewish cultural heritage, thus clarifying anthropology of the city, Ukrainian culture of XIX - early XX century, formation of urbanism and intercultural relations in the modern cultural environment.

\section{References:}

1. Brodelj, F. (1986). Struktury povsednevnosty: vozmozhnoe y nevozmozhnoe. Materyaljnaja cyvylyzacyja, ekonomyka y kapytalyzm, $X V$-XVIII $v$. [Structures of everyday life: possible and impossible. Material civilization, economics and capitalism, XV-XVIII centuries]. Moscow: Proghress, 1 . [in Russian].

2. Docenko, V. O. (2014). Jevrejsjki kuljturno-prosvitnycjki tovarystva ukrajinsjkykh hubernij Rosijsjkoji imperiji (kinecj XIX-pochatok XX st.) [Jewish cultural and educational societies of the Ukrainian provinces of the Russian Empire (late nineteenth - early twentieth century)]. Zb. nauk. pracj KhNPU imeni Gh.S. Skovorody. Serija Istorija i gheoghrafija. [Coll. of scientific works of G. Skovoroda KhNPU. History and geography series]. Kharkiv, 50, 9-14. [in Ukrainian].

3. Kotljar, E. (2011). Evrejskyj Kharjkov: Putevodytelj po ystoryy, kuljture y mestam pamjaty [Jewish Kharkiv: A Guide to History, Culture and Places of Remembrance]. Kharkiv: Centr skhodoznavstva KhDADiM. [in Russian].

4. Kocarev, O. (2020). Leonid Finbergh «Duzhe vazhlyva solidarnistj ukrajinsjkykh i jevrejsjkykh intelektualiv» (intervju v ramkakh fokus-temy Ukrajinsjkogho PEN 2020/2021 «Kuljtura v rezhymi ochikuvannja») [Leonid Finberg «Solidarity of Ukrainian and Jewish intellectuals is very important» (interview within the focus of the Ukrainian PEN 2020/2021 «Culture in standby mode»)] <https://lb.ua/culture/2020/11/03/469689_leonid_finberg_duzhe_ vazhliva.html?fbclid=IwAR02wVM56LLyOMJDueFvzKJIvH1vcghdEmYV9G5mO4Khh0Rh9yJUY3y-L2o> (2020, October, 21). [in Ukrainian].

5. Lotman, Ju. M. (1970). Struktura khudozhestvennogho teksta [The structure of the artistic text]. Mocow: Yskusstvo. [in Russian].

6. Maghochij, P.-R., Petrovsjkyj-Shtern, J. (2018). Jevreji ta ukrajinci: tysjacholittja spivisnuvannja [Jews and Ukrainians: millennium of coexistence, trans. from English O. Forostina]. Uzhghorod: V. Padjak. [in Ukrainian].

7. Melamed, E. (2006). Dokumentjy po ystoryy y kuljture evreev v arkhyvakh Kyeva [Documents on the history and culture of Jews in the archives of Kiev]. Kyiv: Dukh i Litera. [in Russian].

8. Morozova, A. (2005). Yevreyske naselennya Livoberezhnoyi Ukrayiny (Druha polovyna XIX-pochatok XX st.) [Jewish population of the Left Bank of Ukraine (Second half of the XIX-beginning of the XX century)]: avtoreferat dysertatsiyi na zdobuttya naukovoho stupenyu kandydata istorychnykh nauk [Dissertation abstract for the degree of Candidate of Historical Sciences]. Kharkiv: VN Karazin Kharkiv National University. [in Ukrainian].

9. Skidanova, A. (2011). Torghivlja jevrejsjkogho naselennja v Kharkivsjki ghuberniji (drugha polovyna XIX pochatok XX st.) [Trade of the Jewish population in the Kharkiv provinces (second half of the XIX - beginning of the XX century)]. Jevreji v etnichnij mozajici ukrajinsjkykh zemelj [Jews in the ethnic mosaic of Ukrainian lands], 62-67. [in Ukrainian].

10. Ushkalov, L. V. (1999). Z istoriji ukrajinsjkoji literatury XVII-XVIII stolitj [From the history of Ukrainian literature of the XVII-XVIII centuries]. Kharkiv: Akta. [in Ukrainian]. 